\title{
Effect of salivary gland extract from Ixodes ricinus ticks on the proliferation of Borrelia burgdorferi sensu stricto in vivo
}

\author{
Martina Macháčková, Miroslav Oborník and Jan Kopecký
}

Faculty of Biological Sciences, University of South Bohemia and Institute of Parasitology, Academy of Sciences of the Czech Republic, Branišovská 31, 37005 České Budějovice, Czech Republic

Key words: Borrelia burgdorferi, Ixodes ricinus, saliva-activated transmission, salivary gland extract, real-time PCR

\begin{abstract}
Saliva-activated transmission (SAT) of Borrelia burgdorferi sensu stricto was demonstrated using real-time PCR and salivary gland extract (SGE) from partially fed Ixodes ricinus ticks. C3H/HeN mice were injected intradermally with $1.5 \times 10^{3}$ spirochetes mixed with $40 \mu \mathrm{g}$ of SGE per mouse. The control group was inoculated with the same dose of spirochetes without SGE. The accelerating effect of SGE on spirochete proliferation was demonstrated on day 1 post infection, when a 4.2-fold increase in spirochetes was found in the skin and a 10-fold increase in the blood, compared with control mice. The data represent the first direct evidence of a SAT effect of I. ricinus SGE on infection with the Lyme disease agent B. burgdorferi.
\end{abstract}

Spirochetes of the complex Borrelia burgdorferi sensu lato are the causative agents of Lyme disease. In Europe, at least three genospecies are recognized as human pathogens: $B$. burgdorferi sensu stricto, $B$. garinii and B. afzelii (Assous et al. 1993, Van Dam et al. 1993, Wang et al. 1999). Depending on the geographical location, various species of the hard-bodied (ixodid) ticks transmit $B$. burgdorferi s.l. In Central Europe Ixodes ricinus represents an important vector of Lyme disease spirochetes (Oschmann et al. 1999, Grubhoffer et al. 2005).

Feeding of ixodid ticks extends over a number of days and even as long as three weeks. The time required for a tick to obtain a blood-meal provides ample opportunity for interaction with the host immune system. Immune responses of naive hosts involve inflammatory reaction, complement activation and cytokine production (Kopecký and Kuthejlová 1998), preceding activation of adaptive immune mechanisms. Ticks have developed a number of mechanisms that operate against the host immune response. Immunomodulatory molecules present in tick saliva or in salivary gland extract (SGE) affect both innate and adaptive immunity. Tick saliva and/or SGE inhibit activation of the alternative pathway of complement (Ribeiro 1987) and anaphylatoxin activity (Ribeiro and Spielman 1986). Phagocytosis, and production of superoxide by neutrophils and nitric oxide by macrophages, are reduced by tick saliva (Ribeiro et al. 1990, Urioste et al. 1994, Kuthejlová et al. 2001). Tick saliva and/or SGE cause a decrease in inflammatory cytokines IL- 1, TNF- $\alpha$, IL-2, IFN- $\gamma$ and upregulation of anti-inflammatory cytokines IL-4, IL-10 and TNF- $\beta$ (Ramachandra and Wikel 1992, Fereira and Silva 1999, Kopecký et al. 1999, Schoeller et al. 1999, Kuthejlová et al. 2000). The immunomodulatory effect of tick saliva was often studied using SGE, due to the difficulties in obtaining the saliva in sufficient amount. It is obvious that SGE contains also cellular proteins that are not secreted in the saliva. Sometimes, these proteins can influence the host immune response, so that it is different from that affected by tick saliva (Severinová et al. 2005).

Accumulating evidence indicates that immunomodulatory molecules in tick saliva or SGE can promote transmission and survival of $B$. burgdorferi spirochetes in mice (Pechová et al. 2002). This phenomenon is supported by the fact that tick saliva and/or SGE polarize the host immune response to a T-helper 2-type cytokine profile which causes inhibition of spirochete killing, consequently promoting their proliferation. Facilitation of tick-borne pathogen transmission, via the actions of tick saliva on the host, has been termed saliva-activated transmission (SAT). This phenomenon was described as the enhancement of Thogoto arbovirus infectivity when it was inoculated into the host together with SGE (Nuttall and Jones 1991). Existence of SAT can be demonstrated by direct and indirect evidence. Observations of efficient transmission of Borrelia spirochetes between cofeeding ticks without a systemic infection of the host represent indirect evidence of SAT (Ogden et al. 1997). Directly, SAT is demonstrated by enhanced transmission of spirochetes to ticks feeding on a host syringeinoculated with the pathogen plus SGE (Pechová et al. 2002).

Non-bacteraemic transmission has been reported for B. burgdorferi s.s., B. garinii and B. afzelii (Gern and Rais 1996, Patrican 1997, Sato and Nakao 1997, Richter et al. 2002). Borrelia burgdorferi s.s. strain B31 showed SAT with SGE from Ixodes scapularis (its natural vector species in USA), but not with SGE from I. ricinus (Zeidner et al. 2002). We investigated the effect of SGE from I. ricinus ticks on the proliferation of the CB53 
strain of B. burgdorferi s.s. (České Budějovice) in the acute phase of mouse infection. In the Czech Republic, I. ricinus represents the natural vector for spirochetes of the strain CB53.

\section{MATERIALS AND METHODS}

Mice. SPF female $\mathrm{C} 3 \mathrm{H} / \mathrm{HeN}$ mice, 6 to 10 weeks old, were purchased from Charles River, Sulzfeld, Germany.

Borrelia burgdorferi. Two strains of B. burgdorferi s.s. were used: B31 (from dr. Lise Gern, University of Neuchâtel, Switzerland) and CB53, isolated from I. ricinus (ŠtěpánováTresová et al. 1999). Spirochetes were grown in BarbourStoenner Kelly-H (BSK-H) medium (SIGMA) supplemented with $6 \%$ rabbit serum at $34^{\circ} \mathrm{C}$. Bacteria were counted by darkfield microscopy and used at low passage (five or fewer passages).

Salivary gland extract (SGE). Twenty I. ricinus females (colony at the Institute of Parasitology, Academy of Sciences of the Czech Republic, České Budějovice), negative in $B$. burgdorferi s.l. PCR screening, were fed on guinea pigs. After 5 days, engorged ticks were removed and the salivary glands were dissected and pooled. The 5-day period, for which the ticks had fed on guinea pigs, was chosen due to the best effect of SGE prepared from such ticks on the saliva-activated transmission of TBE virus (Labuda et al. 1993). After washing in phosphate-buffered saline (PBS), the salivary glands were homogenized in $1 \mathrm{ml}$ PBS by sonication and centrifuged at $10,000 \mathrm{~g}$ for $10 \mathrm{~min}$. The protein concentration of SGE was determined and aliquots of the SGE were stored at $-80^{\circ} \mathrm{C}$. Before use, SGE activity was tested on mouse splenocytes stimulated with lipopolysaccharide. The active SGE inhibits production of INF- $\gamma$ by these cells (Kopecký et al. 1999).

Experimental infection of mice. A group of 9 mice (BS) was intradermally injected in the ventral thorax area with $1.5 \times$ $10^{3}$ spirochetes in $100 \mu \mathrm{l}$ of BSK-H medium mixed with $40 \mu \mathrm{g}$ of SGE in $50 \mu 1$ PBS per mouse. Forty $\mu$ g of protein can be obtained in SGE from one I. ricinus female. A second group of 12 mice (B) was injected with $1.5 \times 10^{3}$ spirochetes in 100 $\mu \mathrm{l}$ of BSK-H medium mixed with $50 \mu 1$ of PBS only. The control group of 4 mice (C) was inoculated with the same volume of BSK-H medium mixed with PBS. One hour after injection, samples of skin $\left(3 \mathrm{~cm}^{2}\right)$ were taken from the injection site of 3 mice from group B. The skin samples were used to estimate the actual number of inoculated spirochetes.

Tissue samples. On days 1, 3 and 7 post infection (p.i.), 3 mice of group B, 3 mice of group BS and 1 mouse from group $\mathrm{C}$ were used for sample collection. At each time point, samples of the following tissues were taken: 1) blood from the orbital sinus, 2) skin from the injection site, and 3) two pairs of lymph nodes: lymphonodus axillaris proprius and lymphonodus axillaris accessorius. Two hundred $\mu 1$ of blood were taken into microtube with $20 \mu \mathrm{l}$ of $2 \%$ (w/v) EDTA. Skin was weighted after scraping off the subcutaneous fat and put in PBS. Each pair of lymph nodes was placed in PBS.

Extraction of DNA. DNA was extracted using a commercial Jetquick Tissue DNA Spin Kit (GENOMED, Germany). DNA preparation from skin and lymph nodes was performed according to the manufacturer's instructions. For DNA extrac- tion from the blood the supplier's protocol was optimized as follows. One hundred $\mu 1$ of anticoagulated blood was mixed with $20 \mu \mathrm{l}$ of proteinase $\mathrm{K}(20 \mathrm{mg} / \mathrm{ml}$; GENOMED). Volume was adjusted to $220 \mu \mathrm{l}$ with PBS and $200 \mu 1$ of T2 buffer were added. Samples were vortexed and incubated at $70^{\circ} \mathrm{C}$ for 10 min. The additional steps correspond to Part B of Jetquick Spin Column Procedure provided by the producer.

Real-time PCR. For the q-PCR assay, primer pairs and probe for the flagellin gene sequence were used as described by Zeidner et al. (2001). This sequence was later identified as the gene for flagellar filament cap protein FliD (Ge et al. 1997, GenBank accession no. U66699.1), which is localized upstream of the flagellin gene sequence. The dual-labeled probe sequence was 5'-FAM-TGC TAA AAT GCT AGG AGA TTG TCT GTC GCC-TAMRA-3', where FAM refers to the reporter dye and TAMRA to the quencher dye. The reverse primer sequence was identical as described by Zeidner et al. (2001): 5'-ACT CCT CCG GAA GCC ACA A-3'. Amplification using the forward primer described previously (Zeidner et al. 2001) produced irrelevant quantification results, which did not correspond to standard sample concentrations (data not shown). Therefore we designed a new forward primer for qPCR: 5'-CTT CTG GTG GAC TTT CTA GAT-3'. The $20 \mu 1$ q-PCR mixture consisted of $500 \mathrm{nM}$ dual-labeled probe (Generi Biotech), $2 \mu \mathrm{M}$ each primer (Generi Biotech), 2 units of Thermo Start Taq DNA polymerase (AB Gene), $200 \mu \mathrm{M}$ dNTP each (TaKaRa), $2 \mu 1$ of $10 \times$ buffer (AB Gene), $40 \mathrm{ng}$ of extracted DNA; $4.5 \mathrm{mM} \mathrm{MgCl} 2$ and $10 \mu \mathrm{l}$ of $\mathrm{H}_{2} \mathrm{O}$. Following an incubation step at $50^{\circ} \mathrm{C}$ for $2 \mathrm{~min}$ and $10 \mathrm{~min}$ of incubation at $95^{\circ} \mathrm{C}$, the samples were submitted to amplification at $95^{\circ} \mathrm{C}$ for $15 \mathrm{~s}$, at $60^{\circ} \mathrm{C}$ for $1 \mathrm{~min}, 50$ cycles in a Rotor Gene 3000 (Corbett Research). Each specimen was tested in triplicate. Negative controls containing all PCR reaction components with the exception of template DNA (denoted No template control; NTC) were included.

Borrelia burgdorferi quantification standard. We tested real-time PCR with two different B. burgdorferi strains, B31 and CB53, to standardise real-time PCR method using those spirochete strains. Three types of standard were used for qPCR assay. The first type was a plasmid containing the partial sequence of flagellar filament cap protein of B. burgdorferi s.s. CB53 (identical to the sequence in GenBank, accession no. U66699.1). The second type was genomic DNA of $B$. burgdorferi s.s. CB53. For cloning of a FliD partial sequence, a new primer pair was designed: forward primer 5'-GGT GCT TAT AAT GAG GTT CTT GC-3' and reverse primer 5'-GCG CTT AAC GGT AAA ATC CAA GG-3'. For the transformation assay, pCR 2.1-TOPO vector and TOPO TA Cloning Kit (Invitrogen) were used. Ten-fold serially diluted aliquots of both standards mentioned above were prepared. The individual aliquots were used only twice for generation of the standard curve. The third type of standard was the DNA extracted from mouse tissues (skin, blood, lymph nodes) with addition of various concentrations of spirochetes. These standards served as the control of extraction and to test for the potential presence of inhibitors. For converting the concentration values to gene copy number, i.e. number of spirochetes, the following assumption was made: $1 \mathrm{fg}$ of genomic DNA of $B$. burgdorfer $i$ corresponds to one spirochete (Johnson et al. 1992). 
Statistical analysis. Data are presented as number of spirochetes per mg of skin, $\mathrm{ml}$ of blood and per one lymph node. Numbers of Borrelia spirochetes are presented as the mean \pm SEM. The significance of differences in the mean numbers of spirochetes was evaluated by the Student's $t$-test $(\mathrm{p} \leq 0.05)$.

\section{RESULTS}

The q-PCR assay was used for examination of Borrelia burgdorferi infection rate in mouse tissues. As noted in Fig. 1, the amplification plot, in terms of fluorescence intensity versus cycle number, indicates an amplification of serial dilution of B. burgdorferi genomic DNA from 10 to 100,000 copies of FliD gene (i.e. number of spirochetes). The correlation coefficient was routinely between 0.97 and 0.99 (data not shown) and the detection limit of B. burgdorferi DNA was 10 spirochetes per sample. The sensitivity of the real-time PCR was identical when B. burgdorferi sensu stricto B31 and CB53 were compared (data not shown).

Using q-PCR, the effect of I. ricinus SGE on the infection of $\mathrm{C} 3 \mathrm{H}$ mice with $B$. burgdorferi s.s. was tested. Intradermal injection of spirochetes mixed with SGE was compared with injection of spirochetes alone. Analysis of the skin samples one hour p.i. confirmed inoculation of $1.5 \times 10^{3}$ spirochetes/mouse. The enhancing effect of SGE on the proliferation of spirochetes in vivo was detected on day 1 p.i. in the skin and blood (Fig. 2). The average number of spirochetes detected in the skin samples of the BS group $\left(9.6 \times 10^{4}\right.$ spirochetes $/ \mathrm{mg}$ ) was 4.2 -fold higher, but not significantly different from those of group B $\left(2.3 \times 10^{4}\right.$ spirochetes $/ \mathrm{mg}$ ). On the other hand, spirochetes in blood samples of the BS group $\left(8.6 \times 10^{5}\right.$ spirochetes $\left./ \mathrm{ml}\right) \mathrm{sig}$ nificantly outnumbered (more than 10 -fold) those in blood samples of group B $\left(8.5 \times 10^{4}\right.$ spirochetes $\left./ \mathrm{ml}\right)$. At later time points ( 3 and 7 days p.i.) the differences between both experimental groups were not significant (Figs. 3, 4).
The spirochete distribution in various tissues during the acute phase of infection was similar in both experimental groups. A significant increase in spirochete numbers in the skin samples, resulting from their proliferation, was detected on day 7 p.i. in group B $\left(9.4 \times 10^{5}\right.$ spirochetes $/ \mathrm{mg})$ and group BS $\left(7.2 \times 10^{5}\right.$ spirochetes $/ \mathrm{mg}$ ) compared to days 1 and 3 p.i. The decrease in spirochete load in the skin samples $\left(1.1 \times 10^{4}\right.$ spirochetes $/ \mathrm{mg}$ in group B and $4.4 \times 10^{3}$ spirochetes $/ \mathrm{mg}$ in group BS) 3 days p.i. presumably reflected dissemination of Borrelia spirochetes through the blood into lymph nodes. Spirochetes were present in lymph nodes 3 days, and some were detected 7 days p.i. None of the differences between SGE-treated and untreated groups in spirochete numbers in lymph nodes was significant.

\section{DISCUSSION}

Tick saliva-activated transmission of various tickborne pathogens has been demonstrated (Jones et al. 1989, Labuda et al. 1993, Kročová et al. 2003). In the case of Borrelia spirochetes, Pechová et al. (2002) reported indirect evidence for increased bacteraemia in mice injected with $B$. afzelii plus Ixodes ricinus SGE compared with SGE-untreated control mice. An eightfold increase in the number of spirochetes was observed after six days of cultivation in BSK-H medium of blood samples taken on day 1 p.i. from both groups. These results are in good agreement with the results reported here that demonstrate the SAT effect of SGE as early as day 1 p.i., but not later. Another observation supporting the idea of an early effect of SGE on spirochete proliferation was reported in the paper by Pechová et al. (2002). When pathogen-free I. ricinus nymphs were placed on mice infected with spirochetes plus SGE, $57 \%$ of the nymphs became infected compared with no infected nymphs that had fed on mice inoculated with the spirochetes without SGE. This indicates that the

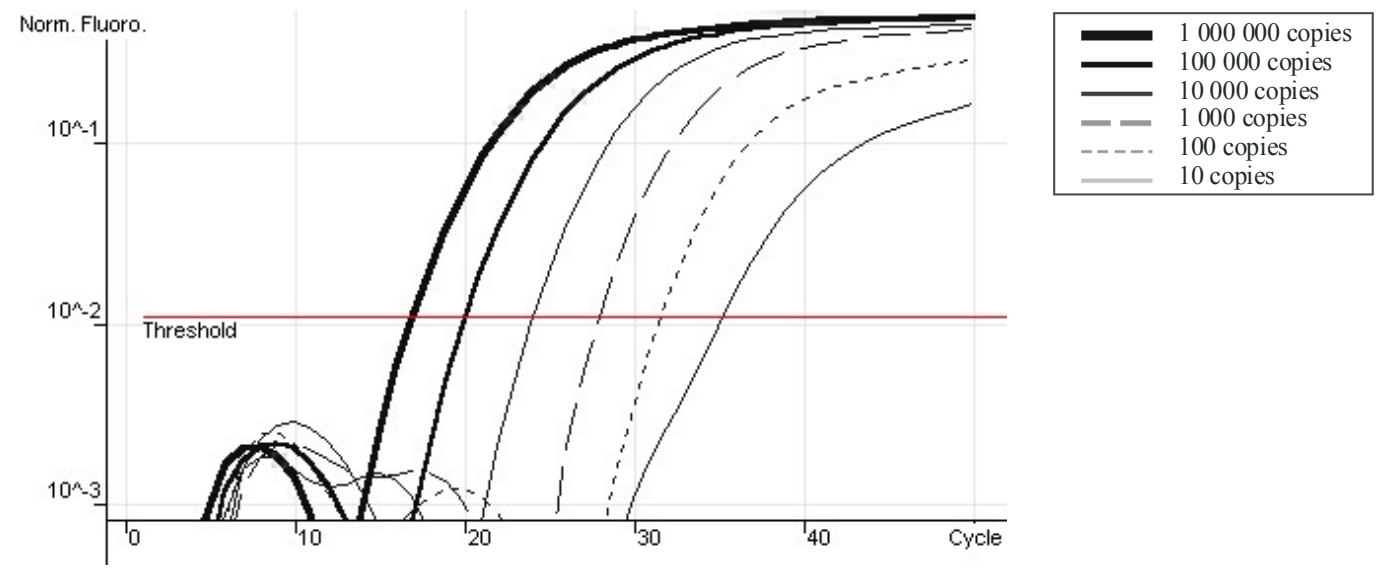

Fig. 1. Amplification plot of Borrelia burgdorferi sensu stricto CB53 quantitative analysis. Individual samples represent standards of spirochete genomic DNA. (The left-to-right sequence of the curves corresponds with the upper-to-lower sequence of the explanations.) 


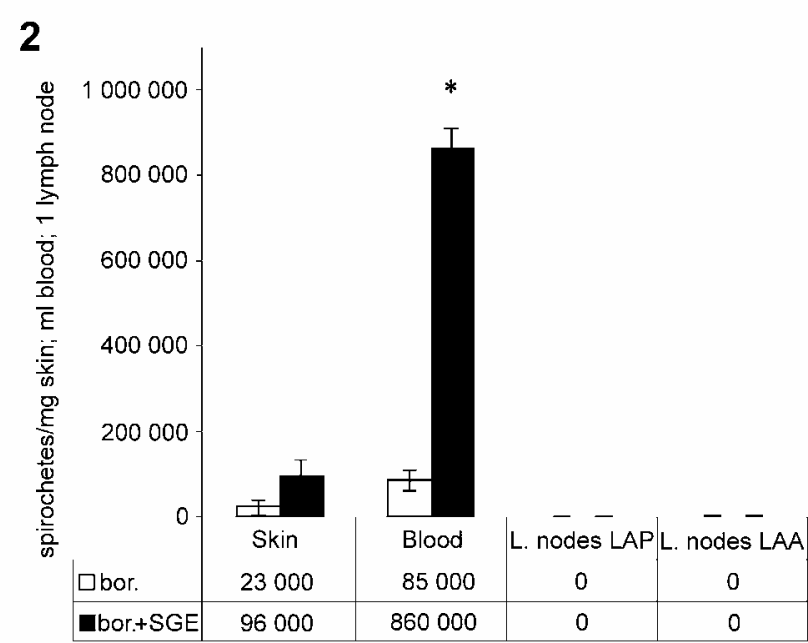

3

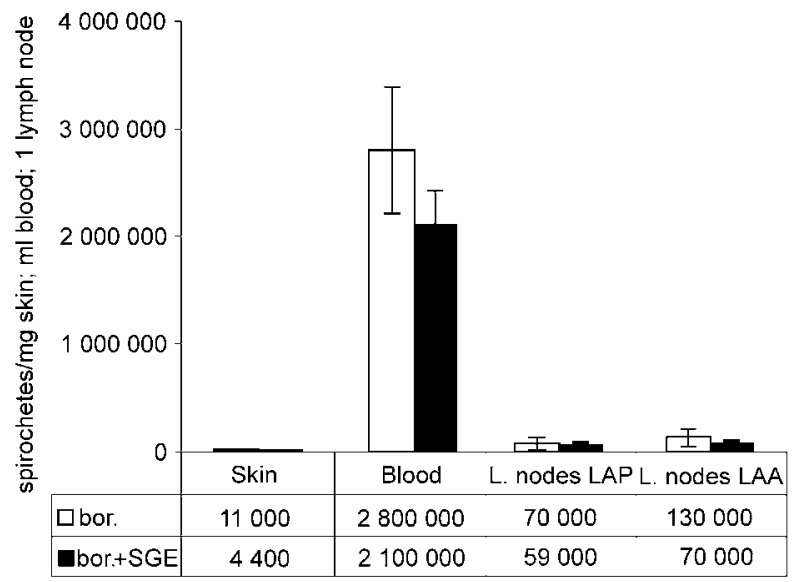

4

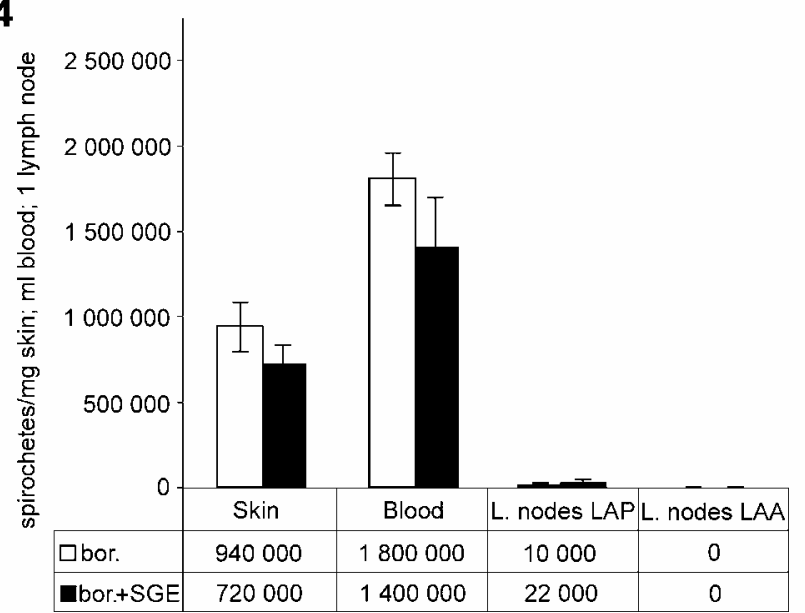

Figs. 2-4. Quantification of spirochetes CB53 in mouse tissues by q-PCR on day 1 p.i. (Fig. 2), day 3 p.i. (Fig. 3) and day 7 p.i. (Fig. 4). The number of spirochetes is presented as the mean \pm SEM. LAP - lymphonodus axillaris proprius, LAA - lymphonodus axillaris accessorius. *Statistically significant difference $(\mathrm{p} \leq 0.05)$ in the number of spirochetes. accelerating effect of SGE occurs during the feeding period, i.e. 3-4 days p.i. The explanation of the very early effect of SGE on the proliferation of spirochetes can reside in its local, short-lasting effect on the skin immune system. At later time points, when the pathogen can be demonstrated in draining lymph nodes, the number of spirochetes was comparable in all examined organs.

In contrast, Zeidner et al. (2002) also demonstrated an enhancing effect of Ixodes scapularis SGE on $B$. burgdorferi spirochete load in target organs, and a similar effect of I. ricinus SGE on Borrelia lusitaniae. However, in this case spirochete numbers were estimated as late as 8 weeks p.i. using real-time PCR.

The enhancing effect of tick saliva on $B$. burgdorferi transmission and proliferation in the host apparently has an immunological basis. The inhibitory effect of tick saliva on early nonspecific immune defences may be responsible for this phenomenon. For example, an inhibitory activity of $I$. ricinus SGE on complementmediated killing of $B$. burgdorferi spirochetes, as well as inhibition of phagocytosis and killing of spirochetes by macrophages, have been demonstrated (Kuthejlová et al. 2001; Kýčková K., Inst. Parasitol. AS CR, České Budějovice - pers. comm.), as has an anti-inflammatory influence of I. ricinus SGE (Severinová et al. 2005). These effects may be connected with anaphylatoxin inactivating activity (Ribeiro and Spielman 1986), histamine-binding activity (Paesen et al. 1999), and/or proinflammatory cytokine-inhibiting activity (Ramachandra and Wikel 1992, Pechová et al. 2004). A direct accelerating effect of SGE on the growth of Borrelia spirochetes in BSK-H medium was also observed ( $\mathrm{Ru}-$ dolf and Hubálek 2003).

The first identification of a SAT factor for Borrelia spirochetes was reported by Ramamoorthi et al. (2005). They showed that the previously described immunomodulatory protein Salp 15 from the saliva of I. scapularis tick (Anguita et al. 2002) binds specifically to the spirochete outer surface protein $C$, protects spirochetes from antibody-mediated killing and enhances the $B$. burgdorferi load in both naive and immune hosts. However, it is not clear whether a similar protein exists in the saliva of the European Lyme disease vector, I. ricinus.

It is obvious that injection of Borrelia spirochetes mixed with tick SGE does not reflect the in vivo situation, when the spirochetes are inoculated by the tick in several small doses mixed with tick saliva for a relatively long period (Sauer et al. 2000). One-shot inoculation of SGE apparently leads to a transient effect on the host immune system due to inactivation or degradation of immunomodulatory molecules mediated by SGE. However, repeated injection of SGE into the site of infection would not mimic the natural infection via tick feeding anyway. Consequently, the most marked effect on spirochete multiplication is observed shortly after inoculation of the pathogen plus SGE. 
Acknowledgements. We are appreciative of advice and comments provided by Julius Lukeš. This work was supported by grants no. 524/05/0811 from the Grant Agency of the Czech Republic, no. MSMT 30-801 from the Ministry of Education, Youth and Sports of the Czech Republic, no. 04-2050-9 from the Student Grant Agency of the University of South Bohemia, Czech Republic, and no. Z60220518 (research project of the Institute of Parasitology, Academy of Sciences of the Czech Republic).

\section{REFERENCES}

ANGUITA J., RAMAMOORTHI N., HOVIUS J.W.R., DAS S., THOMAS V., PERSINSKI R., CONZE D., ASKENASE P.W., RINCÓN M., KANTOR F.S., FIKRIG E. 2002: Salp 15, an Ixodes scapularis salivary protein, inhibits $\mathrm{CD} 4{ }^{+} \mathrm{T}$ cell activation. Immunity 16: 849-859.

ASSOUS M.V., POSTIC D., PAUL G., NEVOT P., BARANTON G. 1993: Western blot analysis of sera from Lyme borreliosis patients according to the genomic species of the Borrelia strains used as antigens. Eur. J. Clin. Microbiol. Infect. Dis. 12: 261-268.

FERREIRA B.R., SILVA J.S. 1999: Successive tick infestations selectively promote a T-helper 2 cytokine profile in mice. Immunology 96: 434-439.

GE Y., OLD I.G., GIRONS I.S., CHARON N.W. 1997: The flgK motility operon of Borrelia burgdorferi is initiated by a $\sigma^{70}$-like promoter. Microbiology 143: 1681-1690.

GERN L., RAIS O. 1996: Efficient transmission of Borrelia burgdorferi between cofeeding Ixodes ricinus ticks (Acari: Ixodidae). J. Med. Entomol. 33: 189-192.

GRUBHOFFER L., GOLOVCHENKO M., VANCOVÁ M., ZACHAROVOVÁ-SLAVÍČKOVÁ K., RUDENKO N., OLIVER J.H. Jr. 2005: Lyme borreliosis: insights into tick- / host-borrelia relations. Folia Parasitol. 52: 279-294.

JOHNSON B.J.B., HAPP C.M., MAYER L.W., PIESMAN J. 1992: Detection of Borrelia burgdorferi in ticks by species-specific amplification of the flagellin gene. Am. J. Trop. Med. Hyg. 47: 730-741.

JONES L.D., HODGSON E., NUTTALL P.A. 1989: Enhancement of virus transmission by tick salivary glands. J. Gen. Virol. 70: 1895-1898.

KOPECKÝ J., KUTHEJLOVÁ M. 1998: Suppressive effect of Ixodes ricinus salivary gland extract on mechanisms of natural immunity in vitro. Parasite Immunol. 20: 169-174.

KOPECKÝ J., KUTHEJLOVÁ M., PECHOVÁ J. 1999: Salivary gland extract from Ixodes ricinus ticks inhibits production of interferon- $\gamma$ by the upregulation of interleukin10. Parasite Immunol. 21: 351-356.

KROČOVÁ Z., MACELA A., HERNYCHOVÁ L., KROČA M., PECHOVÁ J., KOPECKÝ J. 2003: Tick salivary gland extract accelerates proliferation of Francisella tularensis in the host. J. Parasitol. 89: 14-20.

KUTHEJLOVÁ M., KOPECKÝ J., ŠTĚPÁNOVÁ G., MACELA A. 2001: Tick salivary gland extract inhibits killing of Borrelia afzelii spirochetes by mouse macrophages. Infect. Immun. 69: 575-578.

KUTHEJLOVÁ M., PECHOVÁ J., BRAUNFUCHSOVÁ P., KOPECKÝ J. 2000: Effect of salivary gland extract from Ixodes ricinus ticks on the production of various cytokines in vitro. In: M. Kazimírová and P.A. Nuttall (Eds.), Proceedings of the $3^{\text {rd }}$ International Conference "Ticks and Tick-Borne Pathogens: Into the $21^{\text {st }}$ Century". The High
Tatras Mountains, Slovakia, 30 August - 3 September 1999, pp. 165-171.

LABUDA M., JONES L.D., WILLIAMS T., NUTTALL P.A. 1993: Enhancement of tick-borne encephalitis virus transmission by tick salivary gland extracts. Med. Vet. Entomol. 7: 193-196.

NUTTALL P.A., JONES L.D. 1991: Non-viraemic tick-borne virus transmission: mechanisms and significance. In: F. Dusbábek and V. Bukva (Eds.), Modern Acarology, Vol. 2. Academia Prague and SPB Academic Publishing bv, the Hague, pp. 3-6.

OGDEN N.H., NUTTALL P.A., RANDOLPH S.E. 1997: Natural Lyme disease cycles maintained via sheep by cofeeding ticks. Parasitology 115: 591-599.

OSCHMANN P., KRAICZY P., HALPERIN J., BRADE V. 1999: Lyme Borreliosis and Tick-Borne Encephalitis. UNI-MED Verlag AG, Bremen, Germany, 136 pp.

PAESEN G.C., ADAMS P.L., HARLOS K., NUTTALL P.A., STUART D.I. 1999: Tick histamine-binding proteins: isolation, cloning, and three-dimensional structure. Mol. Cell 3: 661-671.

PATRICAN L. 1997: Acquisition of Lyme disease spirochetes by cofeeding Ixodes scapularis ticks. Am. J. Trop. Med. Hyg. 57: 589-593.

PECHOVÁ J., KOPECKÝ J., SALÁT J. 2004: Effect of tick salivary gland extract on the cytokine production by mouse epidermal cells. Folia Parasitol. 51: 367-372.

PECHOVÁ J., ŠTĚPÁNOVÁ G., KOVÁŘ L., KOPECKÝ J. 2002: Tick salivary gland extract-activated transmission of Borrelia afzelii spirochaetes. Folia Parasitol. 49: 153-159.

RAMACHANDRA R.N., WIKEL S.K. 1992: Modulation of host immune responses to ticks (Acari: Ixodidae): effect of salivary gland extracts on host macrophages and lymphocyte cytokine production. J. Med. Entomol. 29: 818-826.

RAMAMOORTHI N., NARASIMHAN S., PAL U., BAO F.K., YANG X.F., FISH D., ANGUITA J., NORGARD M.V., KANTOR F.S., ANDERSON J.F., KOSKI R.A., FIKRIG E. 2005: The Lyme disease agent exploits a tick protein to infect the mammalian host. Nature 436: 573577.

RIBEIRO J.M.C. 1987: Ixodes dammini: salivary anticomplement activity. Exp. Parasitol. 64: 347-353.

RIBEIRO J.M.C., SPIELMAN A. 1986: Ixodes dammini: salivary anaphylatoxin inactivating activity. Exp. Parasitol. 62: 292-297.

RIBEIRO J.M.C., WEISS J.J., TELFORD III S.R. 1990: Saliva of the tick Ixodes dammini inhibits neutrophil function. Exp. Parasitol. 70: 382-388.

RICHTER D., ALLGOWER R., MATUSCHKA F.-R. 2002: Co-feeding transmission and its contribution to the perpetuation of the Lyme disease spirochaete Borrelia afzelii. Emerg. Infect. Dis. 8: 1421-1425. 
RUDOLF I., HUBÁLEK Z. 2003: Effect of the salivary gland and midgut extracts from Ixodes ricinus and Dermacentor reticulatus (Acari: Ixodidae) on the growth of Borrelia garinii in vitro. Folia Parasitol. 50: 159-160.

SATO Y., NAKAO M. 1997: Transmission of the Lyme disease spirochaete, Borrelia garinii, between infected and uninfected Ixodes persulcatus during cofeeding on mice. J. Parasitol. 83: 547-550.

SAUER J.R., ESSENBERG R.C., BOWMAN A.S. 2000: Salivary glands in ixodid ticks: control and mechanism of secretion. J. Insect Physiol. 46: 1069-1078.

SCHOELER G.B., MANWEILER S.A., WIKEL S.K. 1999: Ixodes scapularis: effect of repeated infestations with pathogen-free nymphs on macrophage and $\mathrm{T}$ lymphocyte cytokine response of $\mathrm{BALB} / \mathrm{c}$ and $\mathrm{C} 3 \mathrm{H} / \mathrm{HeN}$ mice. Exp. Parasitol. 92: 239-248.

SEVERINOVÁ J., SALÁT J., KROČOVÁ Z., ŘEZNÍČKOVÁ J., DEMOVÁ H., HORKÁ H., KOPECKÝ J. 2005: Co-inoculation of Borrelia afzelii with tick salivary gland extract influences distribution of immunocompetent cells in the skin and lymph nodes of mice. Folia Microbiol. 50: 457-463.

ŠTĚPÁNOVÁ-TRESOVÁ G., KOPECKÝ J., KUTHEJLOVÁ M. 1999: Identification of Borrelia burgdorferi sensu stricto, Borrelia garinii and Borrelia afzelii in Ixodes ricinus ticks from Southern Bohemia using monoclonal antibodies. Zbl. Bakteriol. 289: 797-806.

URIOSTE S., HALL L.E., TELFORD III S.R., TITUS R. 1994: Saliva of the Lyme disease vector, Ixodes dammini, blocks cell activation by a nonprostaglandin E2-dependent mechanism. J. Exp. Med. 180: 1077-1085.

VAN DAM A.P., KUIPER H., VOS K., WIDJOJOKUSUMO A., DE JONGH B.M., SPANJAARD L., RAMSELAAR A.C., KRAMER M.D., DANKERT J. 1993: Different genospecies of Borrelia burgdorferi are associated with distinct clinical manifestations of Lyme borreliosis. Clin. Infect. Dis. 17: 708-717.

WANG G., VAN DAM A.P., SCHWARTZ I., DANKERT J. 1999: Molecular typing of Borrelia burgdorferi sensu lato: taxonomic, epidemiological and clinical implications. Clin. Microbiol. Rev. 12: 636-653.

ZEIDNER N.S., SCHNEIDER B.S., DOLAN M.C., PIESMAN J. 2001: An analysis of spirochete load, strain, and pathology in a model of tick-transmitted Lyme borreliosis. Vector-Borne Zoonot. Dis. 1: 35-44.

ZEIDNER N.S., SCHNEIDER B.S., NUNCIO M.S., GERN L., PIESMAN J. 2002: Co-inoculation of Borrelia spp. with tick salivary gland lysate enhances spirochaete load in mice and is tick species-specific. J. Parasitol. 88: 12761278. 